\title{
Mestres do domínio dos outros: narrativa e estilo em Seinfeld
}

\section{Masters of someone else's domain: narrative and style in Seinfeld}

\section{Christian Hugo Pelegrini}

Doutor em Meios e Processos Audiovisuais pela Escola de Comunicação e Artes da Universidade de São Paulo (ECA-USP), professor Adjunto do curso de Cinema e Audiovisual do Instituto de Artes e Design da Universidade Federal de Juiz de Fora (IAD-UFJF).

<christian.pelegrini@gmail.com>

\section{RESUMO}

O artigo analisa a série Seinfeld e sua ruptura com as convenções de gênero historicamente construídas na TV americana. Para tal, nossa análise observa duas dimensões da estética do programa: a narrativa e a estilística. Do ponto de vista da estética narrativa, indicamos a ruptura com o modelo dramático orientado a um objetivo (ou o "modelo aristotélico", hegemônico na TV do período). Do ponto de vista estilístico, consideramos o quanto a crescente adoção de práticas de produção pouco comuns levou à constituição de um sitcom híbrido entre o multicâmera e os programas de câmera única.

\section{ABSTRACT}

The paper analyzes the TV show Seinfeld and its breaking with the genre conventions historically constructed on american television. To this end, our analysis points out two dimensions of program aesthetics: the narrative and the stylistic ones. From the narrative aesthetics point of view, we indicated a break with the goal oriented dramatic model (or the "Aristotelian model", hegemonic in the television of such period). From a stylistic point of view, we consider how the increasing adoption of unusual production practices led to the formation of a hybrid between the multi-camera sitcom and the single camera programs.

Keywords: Seinfeld. Narrative. Style.

\section{Introdução}

Brett Mills, num trabalho primoroso em que analisa o sitcom, sugere que a abordagem do gênero deve ser feita não por aquilo que ele é, mas pelo "que ele tem sido" (Mills, 2009, p. 26). Ainda que alguns autores (Caldwell, Morreale) se refiram aos sitcoms como um gênero bastante conservador ao longo das décadas de história da TV, um olhar mais cuidadoso vai identificar certas nuances e mesmo variedade temática e formal entre os programas do gênero. $E$ a cada experiência bem-sucedida, o próprio gênero o assimila, transformandose. Neste sentido, certos programas se tornam historicamente importantes por mudarem seus gêneros, quando não a narrativa seriada como um todo e a própria TV. Dentre tais programas, tomamos como objeto desta reflexão o 
sitcom Seinfeld, exibido pela rede americana NBC, de 1989 a 1998, e ainda hoje bastante reprisado em canais de TV e, recentemente, no serviço de vídeo on demand Hulu.

Mestres de seu domínio, a comédia de palco (o stand up comedy), Jerry Seinfeld e Larry David juntaram forças para criar, em 1989, um especial de TV para Jerry, que eventualmente poderia funcionar como um piloto de uma série de TV - até então, uma zona desconhecida para os comediantes. Certa madrugada, enquanto tentavam desenvolver a ideia, pararam para fazer compras em uma loja de conveniência coreana. Após alguns minutos fazendo comentários engraçados sobre os produtos da loja, decidiram que este deveria ser o teor do programa (Levine, 2010).

Exibido em 5 de julho de 1989, The Seinfeld Chronicles tinha um tom bem diferente das comédias seriadas. O projeto acabou engavetado por alguns meses, até que Rick Ludwin, então chefe do departamento de programas noturnos ${ }^{1}$ insistiu para que a NBC aceitasse encomendar mais quatro episódios a Jerry Seinfeld e Larry David. Incrédulos e convictos que o programa jamais se tornaria uma série regular, os comediantes produziram uma curtíssima primeira temporada. Levine (2010) aponta que isso permitiu que Seinfeld e David dessem conta da encomenda, sem se sentirem pressionados por uma temporada longa (algo muito distante de sua experiência). Ainda com audiências bem modestas, a NBC acabou por escolher o agora batizado Seinfeld como um programa substituto de meio de temporada, com uma encomenda de treze episódios. Esse foi o começo do "programa sobre o nada" que se tornou um dos mais importantes sitcoms da história da TV (Morreale, 2003, p. 175).

A estranha e ousada proposta de "um programa sobre o nada" (Morreale, 2003, p. 175) só teve ressonância por ter sido apresentada ao departamento de programas noturnos da NBC (e não ao departamento de comédias, que recusaria algo tão diferente). Seinfeld tinha claras características de sitcom, mas também muitos aspectos totalmente estranhos ao gênero.

A aposta de Jerry Seinfeld e Larry David acabou evoluindo para uma comédia de observação, mas atenta àquilo que nunca é visto nos outros programas justamente por ser considerado sem importância. Segundo o próprio Larry David,

1 A estrutura administrativa dos canais de TV costuma separar em departamentos cada tipo de programa de sua grade. O departamento de programa noturnos (mais especificamente, o Late night) chefiado por Rick Ludwin cuidava da programação após às 22 horas. 
Toda essa educação e as conversas e a criação familiar que você teve ao longo da vida não te preparam para o número gigantesco de coisas que acontecem. Eu acho que o que acontece na vida das pessoas é que a maior parte do que se passa em suas cabeças, a maior parte de seus dias, é ocupado com minúsculas brigas. É isso o que é a vida das pessoas (David conforme Levine, 2010, p. 12).

Ao contrário dos outros sitcoms, não há uma situação dada de antemão. Em I Love Lucy, Lucy quer ser famosa em todos os episódios; em Dick Van Dyke, Rob Petrie sempre deve produzir textos cômicos para seu chefe e lidar com os problemas domésticos; em Mary Tyler Moore, Mary Richards deve chefiar a edição do telejornal daquele dia. Em Seinfeld, os personagens não tem um programa narrativo fixo; eles não têm aspirações que os impelem através da vida.

Nas primeiras temporadas o programa alcançou audiências estáveis, mas pouco expressivas. No entanto, na temporada de 1992-1993, o programa se tornou muito popular, permanecendo assim até o episódio final, exibido em 14 de maio de 1998.

A série ficcionaliza a vida do próprio Jerry Seinfeld e lhe dá três amigos bastante peculiares. George Constanza (alter ego do próprio Larry David), o melhor amigo de Jerry Seinfeld, "é um dos personagens de mais difícil empatia que já passou pela televisão: inseguro, covarde, mentiroso, desconfiado e rancoroso" (Berciano, 1999, p. 134). Sua ex-namorada, Elaine Bennes, é uma mistura inusitada de superficialidade e egoísmo com determinação e atitude. O vizinho de Seinfeld, Cosmo Kramer, é dono de uma perspectiva muito própria acerca do mundo, na melhor tradição dos personagens de pastelão, incluindose aí uma performance física histriônica. Os episódios começam com Jerry em uma performance de stand up comedy, em que comenta sobre aspectos que, de alguma forma, se conectam tematicamente aos elementos da trama daquele episódio. Tais performances podem voltar no meio do episódio ou mesmo encerra-lo, mas raramente se conectam diegeticamente com a narrativa². As

2 Não é comum que o stand up se refira diretamente ao que ocorre nas tramas. Uma exceção é o episódio "The Red Dot". Jerry inadvertidamente causa uma recaída em um alcoólatra, namorado de Elaine. A recaída o faz perder Elaine e ele passa a culpar Jerry. Bêbado, interpela Jerry em uma de suas performances de stand up no meio do episódio. No entanto, o personagem se recupera e, no final do episódio, volta a interagir com Jerry durante sua apresentação de stand up de encerramento. Desta vez, está sóbrio e acompanhado por uma bela mulher. Bebe uma inocente (e improvável) xícara de café. 
cenas de stand up são autônomas, como muitas cenas da narrativa também serão.

O programa mudou bastante ao longo das nove temporadas. Há uma clara aceleração no andamento a partir da terceira temporada. Também, neste período, o programa deixa de usar a convenção de duas tramas paralelas para construir quatro tramas paralelas (uma para cada personagem), que geralmente colidem no final por alguma peripécia narrativa do roteirista (Levine, 2010, p. 13). Mas Seinfeld, desde o seu começo, apostou em modos muito próprios de conduzir à narrativa e sua dimensão estilística. Com o sucesso da quarta temporada, a liberdade em recusar convenções narrativas e procedimentos técnicos se acentuou. Em termos narrativos, o público já aceitava bem estruturas diferentes do padrão; do ponto de vista do estilo, a audiência lhes garantia certa liberdade de orçamento que era explorada sem reservas.

Esta análise se volta justamente para os aspectos em que Seinfeld se diferenciava dos sitcoms, na sua forma de narrar e nos procedimentos técnicos de produção.

No aspecto narrativo, a alcunha de "programa sobre o nada" (Morreale, 2003, p. 175) escondia uma audaciosa recusa em seguir o modelo predominante na narrativa seriada. O programa é um caso de ruptura com a narrativa aristotélica naTV.

Do ponto de vista do estilo, Seinfeld alterou sobremaneira o modo como se produziam sitcoms ao misturar procedimentos e recursos da produção de câmera única com uma produção tipicamente multicâmera (o modo mais comum para este gênero). Também foi na contramão do gênero ao dar menos importância aos efeitos imediatos da encenação sobre a plateia que assiste à gravação no estúdio e privilegiar a construção de sentido feita na pós-produção. Seinfeld não se coloca pacificamente nas categorias de multicâmera ou câmera única, mas é um sitcom híbrido.

Antes de iniciar nossa análise, cabe um esclarecimento de natureza metodológica. Uma importante diferença entre a análise estética de filmes e de programas de TV é que os últimos, em geral, somam dezenas - quando não centenas - de horas de discurso, ao invés das duas horas habituais de um longa metragem. Assim, embora os fenômenos que apontamos sejam característicos da série como um todo ou apareçam com a frequência mencionada no texto, a marcação de sua ocorrência em cada um dos episódios da série é inviável (e para os propósitos desta reflexão, acreditamos, desnecessária). Desta forma, os episódios nominalmente mencionados aqui são amostras de fenômenos 
regulares ao longo da série; exemplos concretos de escolhas estéticas ao longo das nove temporadas.

\section{Uma narrativa não aristotélica}

O aristotelismo é um conjunto de diretrizes que prescrevem um modo específico de contar uma história. Sua origem, é claro, está no livro Poética, escrito por Aristóteles por volta de 335 a.C. De uma forma geral, o livro trata do funcionamento das narrativas e, especialmente, como estar devem ser feitas. A Poética era composta inicialmente por dois volumes. Há muitas menções ao segundo livro feitas pelo próprio Aristóteles em outras obras e também por outros filósofos ao longo dos séculos. No entanto, a segunda parte do livro se perdeu. Ela versava, dentre outras coisas, sobre a comédia.

O primeiro livro, que chegou a nós, trata dentre outras coisas, do drama e da tragédia. A tragédia é a narrativa que mostra pessoas "melhores que nós", que são dignas de nossa admiração e compaixão. Aristóteles adianta que a comédia fala dos piores que nós, que merecem nosso riso. No entanto, a perda do segundo livro nos impediu de conhecer melhor suas considerações sobre a comédia.

Embora o primeiro livro se volte para como compor uma tragédia, suas diretrizes acabaram por determinar o modelo para narrativas teatrais em geral (Pallotini, 1988). Cabe ressalvar que, mesmo sendo o modelo hegemônico, não é o único. Há muitas narrativas que não seguem o modelo dramático aristotélico, seja no teatro, literatura, cinema e mesmo na TV.

Essa influência da Poética está menos em função do gênero trágico e muito mais em função do modo de apresentar à narrativa: o texto introduz na cultura ocidental a noção de drama. Na concepção aristotélica, drama é ação; uma narrativa encenada e vista diretamente, sem a mediação de um narrador ou de um coro, o que era comum naquela época. Por isso o vínculo tão estreito entre o drama e o teatro.

O drama aristotélico dá ênfase "não a homens, mas a ações" (Roubine, 2003, p. 15). Mas não qualquer ação, feita a esmo. Na Poética, as ações dos personagens são sempre em direção a um propósito, um fim. Aliás, talvez essa seja a principal característica da narrativa aristotélica: ela é orientada a um objetivo dramático.

De modo geral, é a história de um personagem que executa uma ação (ou ações) buscando alcançar um objetivo dramático. A narrativa começa apresentando uma situação de equilíbrio ou estabilidade que se rompe por algum motivo. Neste ponto, o personagem passa a buscar restabelecer 
essa ordem inicial (Lacey, 2000, p. 29). Esse caminho rumo ao objetivo tem obstáculos, que geram conflito e obrigam o personagem a se superar em força ou habilidades, mostrando-se cada vez mais nobre e digno de nossa admiração.

Nossa relação com o drama consiste em um vínculo com o personagem que nos leve a torcer por ele ao longo de seu percurso. Ao final da narrativa, a recompensa do espectador está na experiência vicária do prazer da vitória ou mesmo da dor da derrota do personagem. Essa é a catarse: uma descarga emocional, uma purgação ou purificação da alma que traga o "aprimoramento e o apaziguamento do coração" (Roubine, 2003, p. 19).

Para que o drama funcione de acordo com o descrito (e prescrito) na Poética, alguns cuidados são necessários. A narrativa deve construir uma situação de incerteza acerca do desfecho (o personagem pode ou não alcançar o objetivo). Isso acentua nossa torcida e a respectiva catarse no desfecho.

Alem da incerteza sobre o objetivo dramático, precisamos acreditar, por um momento, que aquilo que está representado é um mundo verdadeiro, não uma encenação. $O$ drama não é o real, mas o que poderia ser (princípio da verossimilhança). Nesse sentido, os eventos da narrativa devem acontecer como uma cadeia lógica de causas e efeitos que se pareçam com um todo coeso e coerente (princípio da necessidade). Não cabe nesta narrativa a intervenção de forças externas a esse mundo ficcional, como soluções mágicas ou coincidências improváveis (o deus ex-machina). O resultado do drama deve ser pelos elementos que fazem parte daquele mundo, mas principalmente pelos esforços do personagem. Para garantir que o drama funcione e cada um dos elementos cumpra sua função de forma adequada, é essencial que cada fragmento do drama (cada cena, cada fala) não somente mova a história em direção ao objetivo dramático, mas faça parte de uma mesma busca pelo objetivo (princípio da unidade de ação).

O funcionamento do drama depende não só deste imitar um mundo possível e lógico, mas que permita ao espectador a plena compreensão do se passa. Assim, o drama deve ser inteligível (Roubine, 2003, p. 25), ou seus efeitos catárticos ao final da narrativa não ocorrerão. Também é importante notar que tal organização, em que elementos e funções do drama contribuem para um fim, constitui uma estrutura dramática específica. E esta estrutura é uma fórmula ou um paradigma que se repete em cada texto narrativo.

O exposto aqui é uma redução ao mínimo necessário dos princípios que constituem o drama aristotélico, mas já deve nos bastar para compreender a relação desta fórmula de drama com nosso objeto, Seinfeld. 
Embora o programa tenha os elementos que normalmente esperamos de uma narrativa audiovisual (personagens, cenários e mesmo ações), estes, com frequência, não se organizam conforme o paradigma aristotélico. Um especialista na série pode objetar e apontar alguns episódios em que essa fórmula acontece sem alterações. Mas estes poucos episódios são exceções; quando considerados os 180 episódios, o que predomina são outros modos de narrar.

Smith (1995) já indicava que Seinfeld tinha estruturas narrativas pouco usuais. Para ele, é comum encontrar na série elementos que compõem a estrutura aristotélica, mas estão dispersos nas linhas narrativas dos quatro personagens. Com essa dispersão, não há a unidade narrativa e, consequentemente, a catarse. O autor vai além e aponta três tipos de estruturas que podem ser encontradas em um único episódio do programa: estruturas sem objetivo, estruturas de antagonismo sem conclusão e variações do modelo canônico sem o efeito de catarse.

O primeiro tipo, estruturas sem objetivo, acontece quando os personagens não agem teleologicamente, em função de algo futuro (um objetivo), mas apenas como reações a eventos passados e seus desdobramentos. No episódio, algum evento narrativo, causado pelo próprio personagem ou mesmo algo fortuito,

Tem consequências diretas e criam situações que os personagens devem confrontar, como na forma canônica. No entanto, estas ações não são tomadas em busca de um objetivo, nem são ações executadas como uma expressão de um traço do personagem (Smith, 1995, p. 84).

Éo caso da brincadeira entre Jerry e George - episódio The Outing $\left(0416^{3}\right)$-, em que fingem serem homossexuais e depois reagem aos desdobramentos disso (a publicação no jornal, a confrontação com suas famílias, o interesse romântico de Jerry e o oportunismo de George para terminar um namoro). Ou na visita que Jerry faz a seus pais (The Pen, 0303), na quente Flórida, em que ele e Elaine precisam lidar com o clima quente (e a recusa de sua mãe em ligar o ar condicionado), a cama desconfortável e a idiossincrasias dos vizinhos idosos.

3 O número, após cada título, refere-se a temporada e a ordem do episódio. Para facilitar a notação, adotaremos a seguinte convenção: os dois primeiros algarismos indicam a temporada; os dois últimos, a ordem do episódio. Assim, “0416” significa que o episódio é da $4^{\circ}$ temporada, e é o 16º episódio. 
Tais situações não remetem a um desfecho: o episódio não consiste em provar que não são homossexuais ou conseguir ir embora da casa dos pais. Não é isso que move os personagens (e a própria narrativa).

O segundo tipo de situação narrativa éaquela gerada por um antagonismo entre dois personagens, em que sua disputa se dá apenas pelo desejo de sobrepujar o outro. O antagonista, nesse caso, não é um obstáculo a um objetivo. Apenas alguém a ser mantido em uma posição inferior, indefinidamente. Basta lembrar-se da conflituosa relação entre Jerry e Newman ou entre George e Lloyd Braun. É uma picuinha sem razão. O antagonismo não se coloca como um entrave para o personagem conseguir algo. O conflito é gratuito e, por vezes, injustificável, acentuando o caráter dos personagens. Basta lembrar-se do episódio The Bubble Boy (0407), em que George se mete um uma disputa infantil com o pernóstico Garoto da Bolha ou na querela entre Jerry e o dentista Tim Whatley, ao longo de cinco episódios diferentes.

Finalmente, Smith aponta que em Seinfeld também se pode observar situações narrativas que recuperam a estrutura canônica, de um objetivo dramático a ser alcançado, a despeito dos obstáculos. Em The Parking Space (0322), George está determinado a ocupar a vaga de estacionamento pela qual briga com Mike; em The Nose Job (0309), Kramer tenta reaver a jaqueta que Ihe dá sorte com as mulheres. No entanto, mesmo quando há um objetivo dramático, este tem contornos muito próprios. Em primeiro lugar, porque essa estrutura conduz a linha narrativa de um ou dois personagens, mas não as linhas narrativas dos outros (que continuam sem objetivo dramático). Além disso, mesmo nas linhas narrativas que se aproximam do modelo canônico e orientam as ações do personagem a um objetivo, três situações podem acontecer: o personagem perde por falhar ou por ação do destino, o desfecho é deus ex-machina ou o personagem alcança o objetivo para se arrepender em seguida.

No primeiro caso, o personagem simplesmente falha em alcançar o objetivo. Isso reafirma a condição cômica dos personagens em sua falta de capacidade ou força de vontade. Ha ainda a situação em que o personagem alcança o objetivo, mas alguma força externa o faz perder novamente, tornando seu momento de êxito fugaz. É o que acontece em The Red Dot (0312), em que George compra uma blusa e paga muito mais barato por ela ter uma mancha (que ele julga imperceptível). Após Elaine recusar o presente com defeito, George tenta aproveitá-la dando à faxineira do escritório com quem tem um caso. À primeira vista satisfeita com o presente, a faxineira acaba percebendo a mancha e recusando a blusa. Em The Fix Up (0316), o mesmo George, sempre malsucedido com mulheres, chega ao fim do episódio envolvido romanticamente com uma 
mulher. No entanto, na última cena, em que estão reunidos em um restaurante, George devora um prato de macarrão de modo nada elegante, causando olhares de repulsa de todos na mesa, especialmente da namorada.

No segundo caso, o personagem alcança o objetivo por outros meios que não as suas ações. Trata-se de uma solução que abusa de coincidências na melhor tradição do deus ex-machina (e logo, contrária ao bom drama aristotélico). Tais soluções, em Seinfeld, costumam ser uma oportunidade para fazer convergir as diferentes linhas narrativas, muitas vezes com requintes de ironia dramática, que faz ressaltar a estética operacional. Mas o principal neste tipo de situação de desfecho, é que o personagem não tem qualquer mérito no modo como alcançou o objetivo, atenuando o efeito do êxito dramático e da catarse. Basta lembrar-se da coincidência que põe nas mãos de Elaine as receitas secretas das sopas de seu nemesis em The Soup Nazi (0706); ou ainda em The Race (0610), em que Jerry vence a corrida contra seu oponente apenas porque um escapamento de carro estourou e confundiu seu oponente e o juiz da disputa.

Por fim, quando o personagem persegue um objetivo, ele também pode alcança-lo para, após muito esforço, perceber que o objetivo não lhe dá a satisfação que imaginava; ou que o prêmio não é tão bom. Isso acontece nas muitas idas e vindas do relacionamento de George com sua noiva, Susan Ross. Ou nas muitas mudanças de emprego de Elaine.

Além dos padrões narrativos expostos por Smith, deve-se apontar, ainda, as muitas linhas narrativas que são deixadas sem qualquer tipo de desfecho. Ao invés de deixar a narrativa em uma situação que, de certa forma, reestabeleça alguma estabilidade, tal cadeia de eventos é sumariamente abandonada no final do episódio. Em The Cheever Letters (0408), Jerry e George tentam escrever um roteiro em diversas cenas ao longo do episódio, mas precisam lidar com sua procrastinação. $O$ episódio termina sem que haja qualquer desfecho para isso. Em The Opera (0409), Jerry e Elaine fogem do louco Joe Davola, que ameaça bater em Jerry e persegue obsessivamente Elaine. Instalados na plateia da ópera, notam que Kramer não está. Ao perguntarem para quem ele vendeu seu ingresso, descobrem que foi para o louco de quem fugiram. O episódio termina ali. Não sabemos se o louco chegou a ocupar o lugar ou o que fez aos dois. $\mathrm{O}$ episódio seguinte não faz menção ao que aconteceu.

De toda forma, quando existe um objetivo dramático em Seinfeld, alcança-lo não tem o mesmo valor que tem em uma narrativa canônica, ou, ainda, não tem valor algum. Isso porque em Seinfeld, ao contrário de um drama aristotélico, a recompensa do espectador não está na experiência vicária de 
vitória ou derrota. Não é o desfecho possível que faz o espectador assistir até o final do episódio.

Ao invés disso, a série compensa o espectador com os muitos momentos cômicos que acontecem ao longo da narrativa, em fragmentos autônomos que provocam uma catarse dispersa em toda a narrativa (e não acumulada no final). Os fragmentos podem ser um diálogo engraçado, uma mera observação ou comentário feito por um dos personagens, uma reação idiossincrática ou uma performance de comédia física (como as entradas de Kramer no apartamento de Jerry ou os empurrões de Elaine nos outros personagens). Tais fragmentos cômicos não respeitam o princípio da unidade de ação, uma vez que não movem a narrativa adiante (em direção ao objetivo). Muitas vezes, sequer tem qualquer relação com o que acontece na trama, sendo uma digressão aos seus eventos (Levine, 2010, p. 12). A repetição de tais fragmentos sustenta o espectador até o final, quando a resolução passa a ser secundária. O prazer de assistir já aconteceu. Se a forma como a trama vai terminar é secundária, basta abandonála aos vinte e quatro minutos de narrativa.

A dimensão narrativa de Seinfeld deve ser observada à luz de seu contexto. Se afirmamos que o programa sistematicamente evitou a estrutura dramática aristotélica, também é importante notar o quanto isso era pouco usual na TV aberta do começo dos anos 1990. Mais uma vez, voltemos ao aristotelismo.

Embora o modelo de drama aristotélico não tenha sido tão recorrente na cultura latina e no teatro medieval, ele será redescoberto no Renascimento e ganhará força na França, durante o século XVII. É esse drama aristotélico que alcançará o final do século XIX, quando o inchaço dos grandes centros urbanos demandou novas formas de entretenimento para as massas. Na virada do século, o aristotelismo alcança

[...] uma era em que havia uma enorme expansão das mídias narrativas em geral. Durante o final do século XIX, as baratas revistas de ficção popular se espalhavam pelos EUA e pela Grã-Bretanha. Nos Estados Unidos, companhias dramáticas itinerantes apresentavam peças populares, como a Cabana do Pai Tomás, na maioria das cidades. Junto com essa expansão, veio a necessidade por mais escritores para produzir histórias. Ao aprender seu trabalho, esses escritores se voltaram para versões simplificadas de noções clássicas do que constitui uma história. Em particular, as estruturas de Aristóteles acerca de começos, meios e finais, e sua visão sobre unidade [narrativa] foram amplamente repetidas em manuais de como fazer para cada arte narrativa (Thompson, 2003, p. 19-20). 
Esse movimento chega às mídias audiovisuais do século XX. Ele vai constituir os códigos narrativos do cinema clássico americano ${ }^{4}$ e da dramaturgia radiofônica. Com o surgimento da TV, esta emprega o mesmo modelo narrativo que fora usado nos folhetins, no teatro popular, no cinema clássico e no rádio.

Isso não quer dizer que o aristotelismo seja o único modelo dramatúrgico praticado. Para nos limitarmos a apenas alguns nomes, basta olhar para as obras teatrais de Bertolt Brecht e de Samuel Beckett; ou os filmes de Goddard e de Resnais, por exemplo. Mas na TV, sua economia industrial sempre favoreceu o modelo aristotélico. $O$ interesse em manter altos índices de audiência levou os executivos a valorizarem conteúdos acessíveis, na lógica do menor denominador comum para os diferentes públicos que poderiam estar assistindo ao seu canal ${ }^{5}$. O drama aristotélico é uma opção palatável justamente por ser tão comum. Para o espectador de TV do século XX, as histórias contadas desse modo seguem uma fórmula que ele conhece bem.

E assim foi na consolidação da narrativa de ficção seriada por décadas. Em séries policiais, médicas, telenovelas e soap operas, o modelo aristotélico era hegemônico. E também nos sitcoms. Como já indicamos em trabalhos anteriores, os sitcoms televisuais tem origens radiofônicas, mas a passagem para a TV acabou por adapta-lo em um modelo muito próximo de uma apresentação teatral.

Ao longo de sua história, o sitcom acabou sendo, quase na sua totalidade, estritamente aristotélico. Podemos tomar episódios de um sitcom qualquer - I Love Lucy, Bewitched, The Dick Van Dyke Show, The Andy Griffith Show, M.A.S.H., Happy Days, Family Ties, Golden Girls etc, e notaremos que tudo começa apresentando uma ruptura na ordem. O episódio consistirá, então, do personagem (ou personagens) tentando reestabelecer essa ordem (e, em geral, conseguem lá pelo final do episódio). A narrativa é orientada para este objetivo. A ocorrência dos momentos cômicos se dá quase sempre como consequência da ação do personagem, de forma bastante integrada ao todo.

4 Basta lembrar que Griffith se fiava nas narrativas de Dickens (de quem sempre tinha um livro nas mãos durante as filmagens). Para mais detalhes sobre o modelo no cinema clássico, ver BORDWELL, David. "O Cinema clássico holywoodiano: normas e princípios narrativos" in RAMOS, Fernão Pessoa (org.). Teoria Contemporânea do Cinema (volume II): Documentário e narratividade Ficcional. São Paulo, Ed. SENAC, 2005.

5 O LOP ou Least Objectionable Program (Programa Menos Objecionável) é uma teoria formulada pelo executivo da NBC Paul. L. Klein, na década de 60, que afirma que a audiência de TV procura os programas que lhe sejam menos desagradáveis e/ou exigentes, e não por aquilo que cada indivíduo deseja especificamente. Hoje, pesquisas indicam que isso é uma redução grosseira do comportamento do espectador, mas tal princípio norteou o gerenciamento das programações por décadas. 
Seinfeld, neste sentido, acaba por atualizar modelos narrativos que não são comuns em séries de ficção. A comédia feita de fragmentos cômicos autônomos está presente em diversas formas de performance ao longo da história do entretenimento. Suas raízes modernas podem ser detectadas nos espetáculos de variedades, nas atrações de circos, feiras e vaudevilles.

Tais modelos narrativos atravessam o chamado primeiro cinema e chegam à indústria já formada como as comédias de comediantes (comedian comedys) que "não se organizavam de acordo com a estética baseada em narrativa do cinema clássico"(Krutnik, 1994, p. 17). No entanto, porvolta da década de 1920, um movimento de transição começa a ser percebido em filmes de longa metragem de Chaplin, Keaton e Loyd, no qual "as gags começam a surgir da narrativa, ao invés de competir com ela" (Krutnik, 1994, p. 19). O domínio da narrativa sobre o fenômeno cômico pode ser notado, por exemplo, ao compararmos filmes dos Marx Brothers de fases diferentes. A fase que vai de Cocoanuts (1929) a Duck Soup (1933) é de natureza fragmentada, "dando pouca atenção para as normas 'clássicas' de motivação e causalidade" (Krutnik, 1994, p. 20). Já os filmes da fase MGM, como A Night in the opera (1935) e A Day in the Races (1937), mostra "um movimento em direção a uma 'formalização' resultando em um ordenamento mais enfático de sua performance cômica 'disruptiva' em relação a um processo narrativo claramente definido" (Krutnik, 1995, p. 20). Nesta fase, os Marx Brothers não eram mais protagonistas, mas coadjuvantes de uma trama romântica.

No rádio, acontece um processo semelhante. O rádio assimilou os formatos de variedades para preencher suas muitas horas de programação, incluindo-se aí a contratação de artistas que já eram conhecidos pelas apresentações de palco (Mintz, 1988, p. 92). Como já analisou David Marc (2005, p. 21), tais programas de variedades constituem uma das ascendências genéricas do sitcom de TV. Marc relata que os programas eram apresentados por artistas que faziam a transição entre números musicais, imitações, outros comediantes e tudo o que fosse veiculável pelo rádio. Aos poucos, as constantes intervenções cômicas dos apresentadores começaram a constituir uma narrativa, que era retomada a cada intervenção. Programas como os The George Burns and Gracie Allen Show e The Jack Benny Program consolidaram os fragmentos cômicos em narrativas inteiras (e participaram do surgimento do sitcom de TV).

Não são poucos os autores que afirmam ser a TV herdeira de muitas formas de atração de variedades (Krutnik e Neale, 1990, p. 179). E essa condição pode ser observada em boa parte da sua heterogênea programação. Programas de esquetes, entrevistas, revistas temáticas, esportes e apresentações "ao vivo" retomam a comicidade fragmentada e autônoma, desvinculada de um modelo 
narrativo baseado em Aristóteles. No entanto, a ficção seriada televisual sempre teve uma extrema dependência dos modelos oriundos da ficção radiofônica (seriada ou não) e, por consequência, um certo parentesco formal com os modelos do cinema clássico. O feito de Seinfeld, neste sentido, foi unir essa natureza dupla da TV, combinando um gênero (a ficção seriada) com um modo narrativo não aristotélico.

\section{Hibridização e estilo}

Além das mudanças na dimensão narrativa, Seinfeld também alterou sensivelmente as práticas de encenação, cinegrafia, montagem e sonorização utilizadas nos sitcoms multicâmera desde a década de 1950. As condições em que o programa foi criado sugeriam, ao menos da parte dos produtores, que se adotasse o econômico e rápido modo multicâmera, com todas as implicações estéticas decorrentes dessa escolha. No entanto, não eram esses os planos de Larry David, que havia idealizado o programa feito em câmera única (Levine, 2010, p. 18). Embora a decisão tenha pesado em favor da economia da multicâmera, bem cedo o programa começou a experimentar com procedimentos e recursos de linguagem nada comuns nesse modo de produção. Seinfeld recorria com frequência a formas de registro e produção de sentidos típicos de programas feitos em câmera única, embora a maior parte de cada episódio permanecesse em multicâmera. Nesse sentido, o programa pode ser considerado um híbrido dos dois modos de produção.

Em outro trabalho já analisamos as características da produção multicâmera em considerável detalhe. Para esta reflexão, cabe apenas resgatar algumas características muito básicas. O sitcom trabalha com uma forma bem específica de multicâmera, evitando o corte feito "ao vivo" com uma switcher ${ }^{6}$. Ao invés disso, três ou quatro câmeras gravam ininterruptamente uma encenação que transcorre inteira no estúdio (com óbvias interrupções entre as cenas), de modo muito parecido com uma encenação teatral. Posteriormente, o material das três (ou quatro) câmeras é editado com planos selecionados do material bruto, numa composição de planos gerais e primeiros planos que mostrem adequadamente a interação entre os personagens.

Esse é o modelo idealizado pelo diretor de fotografia Karl Freund para I Love Lucy no final de 1951 e rapidamente tornado padrão para a produção de sitcoms por uma indústria ávida em economizar tempo e dinheiro. Além da

6 Embora a maioria trabalhe com esta versão do multicâmera, alguns poucos programas cortaram "ao vivo" (All in the Family e Everbody Loves Raymond). 
dimensão econômica, o modo multicâmera também se prestava muito bem a registrar a encenação feita em frente a uma plateia. A opção de encenar diante de espectadores no estúdio, com a incorporação de seu riso imediato, é um importante elemento do sitcom desde a década de 1950 até os dias atuais. Para os atores, a resposta do público tem efeitos diretos na performance cômica; para produtores, o riso de quem assiste no estúdio contagia os espectadores em casa, acentuando os efeitos cômicos do programa.

A gravação em multicâmera impõe restrições de estilo ao texto audiovisual. Neste modo de produção, quase tudo é pensado para funcionar "ao vivo", mesmo que o material seja editado posteriormente. Cinegrafia, som e luz precisam funcionar "de primeira" para não sacrificar a integralidade da cena e demandar repetições em frente à plateia. Este modo de produzir desloca toda a narratividade e a formação de sentidos para a encenação, especialmente para as interações verbais entre os personagens (os diálogos). Tudo o que deve acontecer, acontece no material pró-fílmico (o que está diante das câmeras). A participação do aparato narrativo, neste sentido, está em apenas registrar adequadamente os eventos encenados, em uma dinâmica de planos e contraplanos conduzida pelo diálogo. Embora já tenhamos apontado que mesmo neste regime de redução de estilo é possível perceber diferenças e opções criativas quando comparados entre si (Pelegrini, 2014), à luz dos sitcoms de câmera única estes parecem mais uma "mostração"7 do que é encenado do que uma narração propriamente dita.

Dispostas na linha da "quarta parede" do cenário, as câmeras tendem a capturar planos gerais da cena e planos mais fechados cruzados, formando os planos/contraplanos ideais para os diálogos rápidos e reações faciais. No entanto, as câmeras dificilmente avançam em direção à cena, sob o risco de serem "vistas" pelas outras câmeras. Isso elimina a possibilidade de planos subjetivos e certos detalhes de cena. Também é pouco comum que as câmeras façam plongés e contraplongés, uma vez que tais ângulos poderiam revelar as luzes do estúdio (e a inexistência de teto no cenário). Além disso, os enquadramentos e principalmente os movimentos de câmera precisam ser restringidos ao mínimo (e mais simples) possível, pois a captura da cena tende a ser feita integralmente, e um movimento errado ou enquadramento ruim poderia arruinar aquela encenação.

7 Na acepção que lhe dá André Gaudreault, a "mostração" é um audiovisual bruto, não manipulado pelo movimento de câmera, pela variação do enquadramento e pela montagem; opõe-se a "narração" cinematográfica. Ver Gaudreault e Jost, A narrativa cinematográfica. Brasília, Editora da UNB, 2009. 
Não há margem para muita elaboração do som, que deve ser uma captura correta das interações verbais entre os personagens, sem muitas microfonagens diferentes e foleys de cena. A intensidade do diálogo raramente se suaviza para evitar perder uma fala.

A montagem raramente sai da função narrativa, sendo draconianamente determinada pelos diálogos e, em ultima instância, pela encenação no estúdio. A margem para montagens que produzam sentido, como as discursivas ou as montagens de correspondências, se reduzem muito. O que deve ser visto é o que foi encenado, da forma como foi encenado. A manipulação do tempo pela montagem pode acontecer, mas também é bem menos intensa que nas produções de câmera única. É comum que encenações sejam feitas duas vezes, e o editor tem a disposição duas séries de cenas para escolher os fragmentos; também acontece de uma ou outra cena específica (ou um pedaço dela) ser repetida após a saída da plateia. Mas o tempo construído na montagem ainda é determinado pela cena. Instantes mortos são eliminados e ajustes acontecem para fazer o episódio caber na duração do programa, mas o sentido do encenado é a razão máxima a guiar qualquer corte.

Quando observamos o estilo em Seinfeld, é possível notar uma crescente experimentação com o passar das temporadas, quando o programa já não se limitava mais ao modo de produção multicâmera e a seus desdobramentos estéticos. Embora o modo predominante ainda fosse o limitado multicâmera, o programa muitas vezes driblou seus cânones da mesma forma que o fizera com a dimensão narrativa.

Os recorrentes planos e contraplanos que tão prontamente caracterizam os sitcoms clássicos acontecem, mas tem uma dinâmica própria. Não há a cadência de "preparação, piada, preparação, piada, como a maioria dos sitcoms" (Ackerman, 2007, 5'40"). Embora algumas trocas de turno do diálogo sigam o andamento usual, muitas falas dos personagens são observações sobre as coisas que acontecem no cotidiano (a característica do programa) e acabam sendo falas bem mais longas e autônomas. Com isso há muitos planos longos no meio do diálogo (o que não é usual).

Seinfeld também usou com frequência o recurso de recusar um contraplano aos espectadores. Na contramão das convenções do gênero, muitas cenas se desenvolviam sem que pudéssemos ver com quem ou o que o personagem interagia, o que acentuava certos efeitos cômicos. Há uma ruptura de expectativa que não é semântica, mas sintática. Sitcoms da mesma época também utilizavam tal recurso. Basta lembrar, por exemplo, de Friends e do apartamento vizinho ao de Mônica, cujo ocupante vivia nu (mas nunca 
era mostrado). No entanto, Seinfeld criou uma variedade de situações em que o expediente da recusa do contraplano era explorado. É o caso do episódio The Nose Job (0309), em que o resultado desastroso de uma rinoplastia só é visto pelos personagens, mas não pelo espectador. Só o que vemos é a reação dos personagens ao rosto desfigurado. Ou do antológico The Bubble Boy (0407) - cujo personagem título só conhecemos pela voz e o comportamento antipático. Há mesmo um personagem que nunca é visto, Mr. Steinbrenner, chefe de George nos Yankees. Em diversos episódios, Steinbrenner nunca é mostrado de frente. Sempre vemos a cena com a câmera acima de sua cabeça, em sua perspectiva.

- Figura 1 - A negação do contraplano produz sentido e comicidade

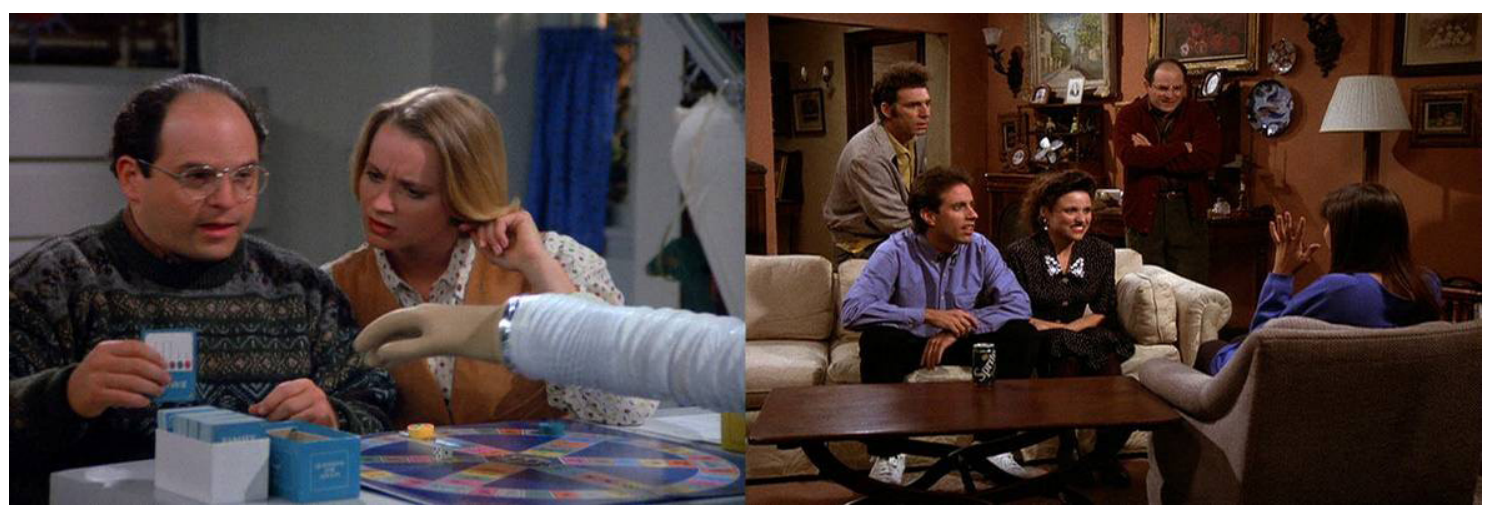

Fonte: DVD Seinfeld, $4^{\mathrm{a}}$ temporada, The Bubble Boy (0407)

O programa também fez uso de enquadramentos bastante diferentes do limitado sitcom clássico. A partir da quarta temporada, quando o programa alcançou números de audiência bastante expressivos e uma posição de destaque na programação da NBC, os produtores puderam dar mais liberdade aos roteiristas para a criação de situações inusitadas. E tais situações acabaram implicando uma cinegrafia que se parecia mais com aquelas feitas em programas de câmera única.

A gravação de planos no estilo single camera tinha duas implicações imediatas. A primeira dizia respeito ao custo de gravar fora do esquema de multicâmeras em estúdio. O diretor Tom Cherones (2011, 44'30"), principal diretor até a quinta temporada, lembra que a Castle Rock (que produzia Seinfeld) se mostrava bastante condescendente com as extravagâncias do programa. Isso os levou a experimentar com planos que eram difíceis e demorados para gravar. O segundo problema era que tais planos funcionavam muito pouco com a plateia que assistia à gravação no estúdio. Eram muito adequados para inserts na montagem, mas pouco funcionais "ao vivo". 
É o caso das subjetivas, que aparecem em Seinfeld com certa frequência. No já comentado The Nose Job (0309), a subjetiva de George é feita com uma lente bastante curta, acentuando o tamanho do nariz de sua namorada.

Figura 2 - 0 tamanho exagerado do nariz só existe para os que assistem pela TV

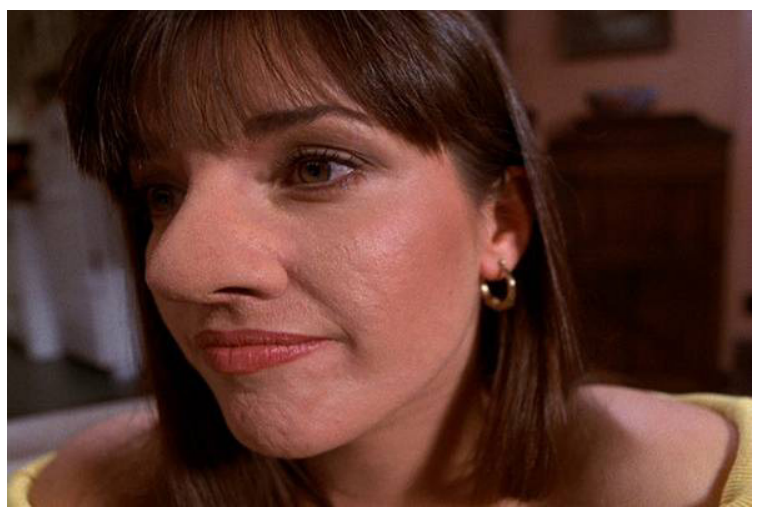

Fonte: DVD Seinfeld 3a temporada, “The Nose Job” (0309)

Ou no episódio The Pitch (0403), em que Kramer acidentalmente vomita na nova namorada de George, Susan. Não só há um plano subjetivo, como esse plano é feito em movimento, representando o deslocamento do personagem em busca de um "melhor local" para vomitar.

- Figura 3 - Um plano subjetivo pouco comum para produções multicâmera

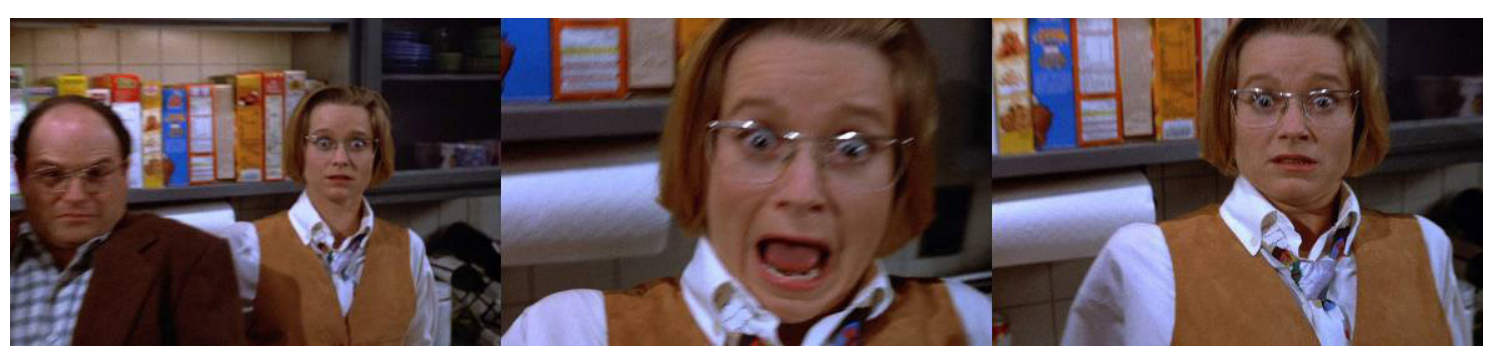

Fonte: DVD Seinfeld 4a temporada, The Pitch (0403)

Há mesmo máscaras que marcam a imagem como capturada por algum dispositivo diegético, que depois é usado como recurso cômico. É o caso da fotografia em The Pen (0303) e da câmera de vídeo com que Kramer sugere um pornô com Elaine e George em The Tape (0308). 
Figura 4 - Câmeras diegéticas, nunca percebida pela plateia que assiste ás gravações

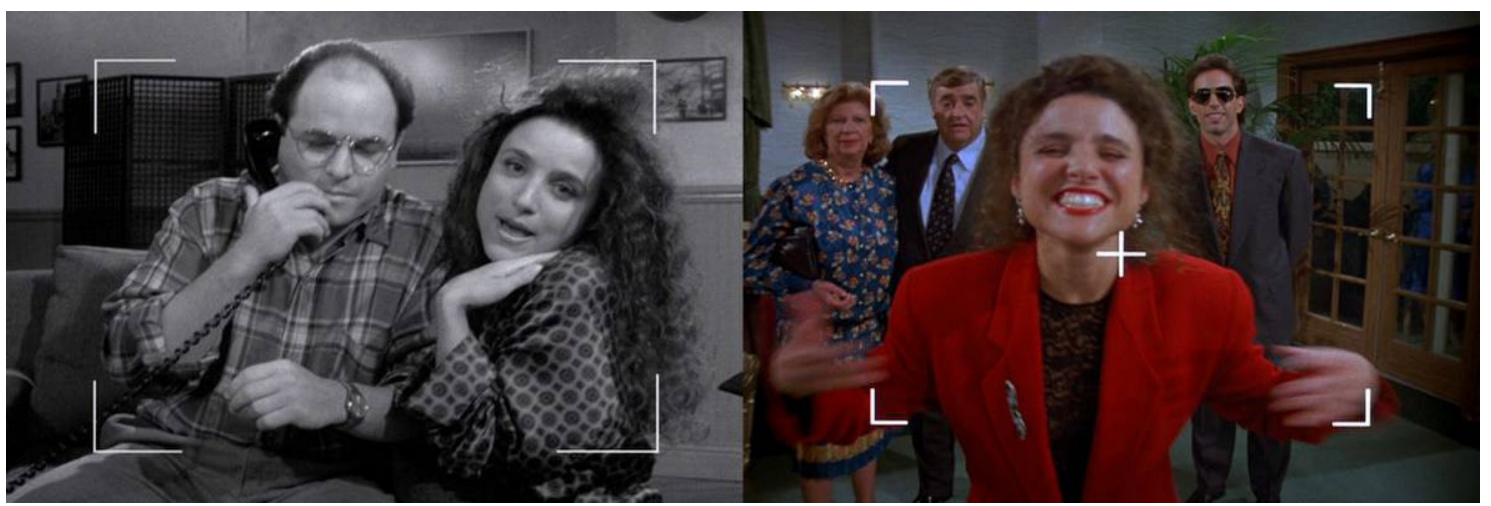

Fonte: DVD Seinfeld $3^{a}$ temporada, The Pen (0303); The Tape (0308)

Além dos planos subjetivos, alguns planos fazem uso de ângulos que reiteram o princípio da ubiquidade da câmera, recurso típico das produções de câmera única. Em The Pothole (0816), quando Jerry acidentalmente deixa a escova de dente de sua namorada cair no vaso sanitário, vemos sua reação em uma inusitada perspectiva de dentro do vaso. O plano, que levou mais de quatro horas para ser gravado e demandou a construção de uma plataforma onde foi colocado o sanitário com fundo de vidro (Ackerman, 2007, 15'), durou na tela apenas alguns poucos segundos.

Figura 5 - 0 plano em The Pothole: quatro horas para gravar; poucos segundos na tela

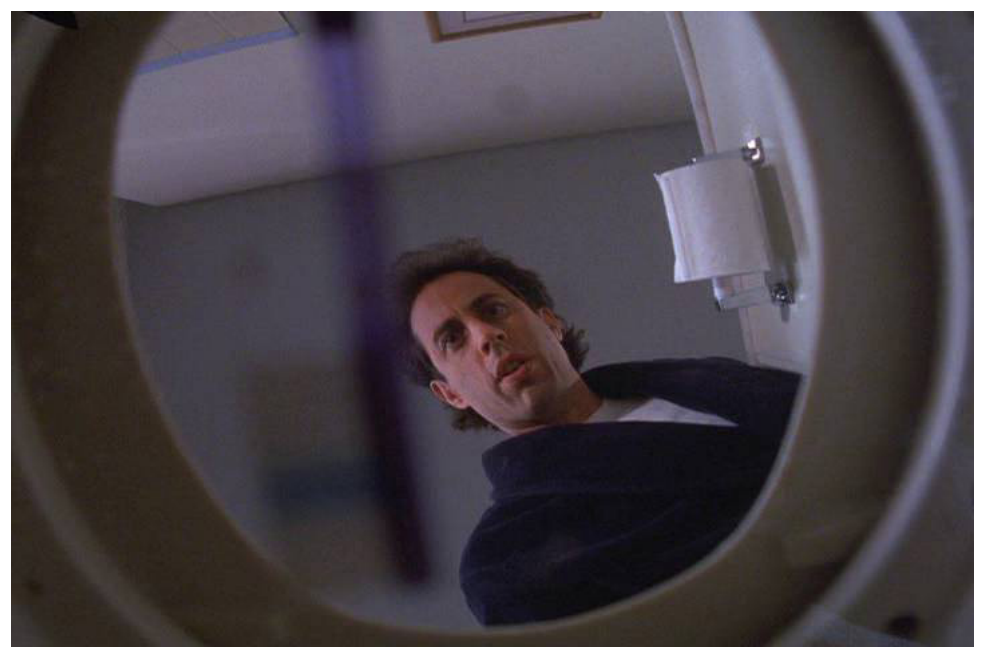

Fonte: DVD Seinfeld 8a temporada, The Pothole (0816) 
Algo parecido ocorre no episódio The Boyfriend (0317), quando Jerry e Kramer vão visitar amigos que tiveram um bebê incrivelmente feio. Vemos a reação dos personagens pela perspectiva do bebê. Como no plano de "The PotHole", a câmera em contraplongé (ângulo baixo) exige que se construa um teto para o cenário, evitando que o grid de luz apareça.

\section{Figura 6 - Um pouco comum contraplongé}

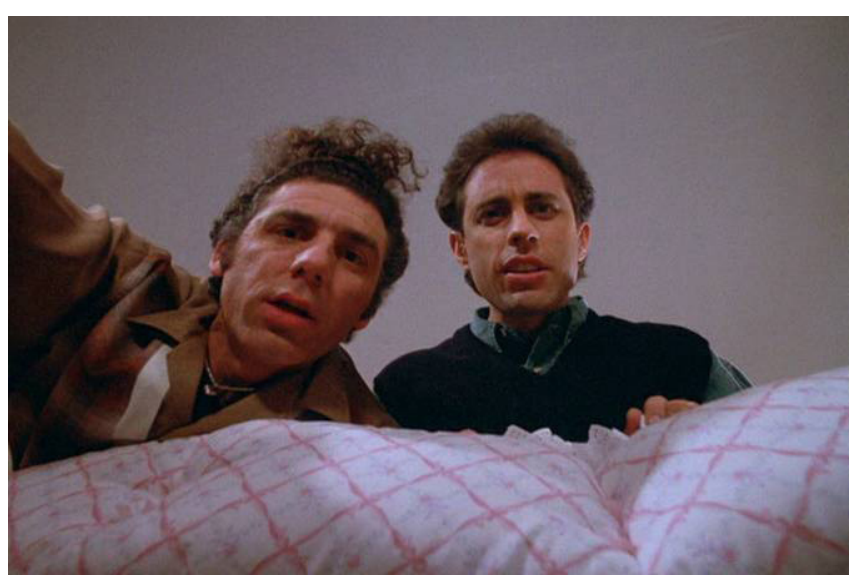

Fonte: DVD Seinfeld $3^{a}$ temporada, The Boyfriend (0317)

Ainda no mesmo episódio, há uma cena em que a câmera faz um inusitado contraplano em direção à plateia, que não é mostrada pelo plano ser em plongé. O plano mostra Jerry entrando em seu apartamento e vendo o amigo George, com calças arriadas, estirado no chão da sala. Tal plano precisou ser gravado em separado da cena e inserido posteriormente ${ }^{8}$.

Tais planos (Figura 7) têm grande potencial cômico, mas impedem que a plateia do estúdio aproveite essa comicidade ali, durante a gravação. As sofisticações técnicas são difíceis de conciliar com a encenação "ao vivo"9

8 De fato, o plano não estava planejado e foi incorporado a partir de um ad lib (um improviso) de Jerry Seinfeld. Anteriormente, no episódio, George pede a Jerry que finja ser o dono de uma empresa de látex onde George teria ido procurar trabalho. Pois ao entrar em seu apartamento e flagrar o amigo em tão constrangedora posição, Jerry improvisa um "E você quer ser meu vendedor de látex?". Gostaram tanto da fala que ela foi mantida na edição. O plano foi feito para garantir o sarcasmo da pergunta.

9 É interessante observar o que ocorrera anos antes com o sitcom Barney Miller (ABC, 1975-1982). Idealizado para ser produzido em multicâmera e gravado na presença de uma plateia, o programa abordava o cotidiano de uma delegacia do Greenwich Village em Nova York. Muito do que era gravado com a plateia no estúdio era reencenado depois, buscando nuances de performance dos atores em momentos mais sérios. Tais regravações duravam horas por serem repetidas com o mesmo tipo de exigência comum à câmera única. Após algumas temporadas, o criador da série e produtor, Danny Arnold, criava longas cenas inteiras durante a gravação, paralisando o trabalho por horas. Arnold também passou a exigir uma sofisticação com a luz da delegacia que permitisse criar dramaticidade em certas cenas, demandando horas de ajustes (ainda que mantivesse a gravação em multicâmera). Em pouco tempo, a gravação em frente à plateia foi abolida. 
justamente por serem tão demoradas e ter o seu efeito construído pela narração: o nariz só fica gigante olhado pela lente curta, a reação de Jerry é muito mais engraçada quando vista "de dentro" da privada.

A produção do programa sempre se esforçou para conciliar tais cenas com a plateia do estúdio. Foram muitas as sequências filmadas fora do estúdio, geralmente feitas também com multicâmera (Cherones, 2011, 45'13"). Quando isso ocorria (The Soup Nazi 0706), a sequência ou cena era exibida para a plateia usando monitores de vídeo, e intercalada com a encenação que ocorria "ao vivo".

\section{Figura 7 - Um contraplano que não revela a plateia}

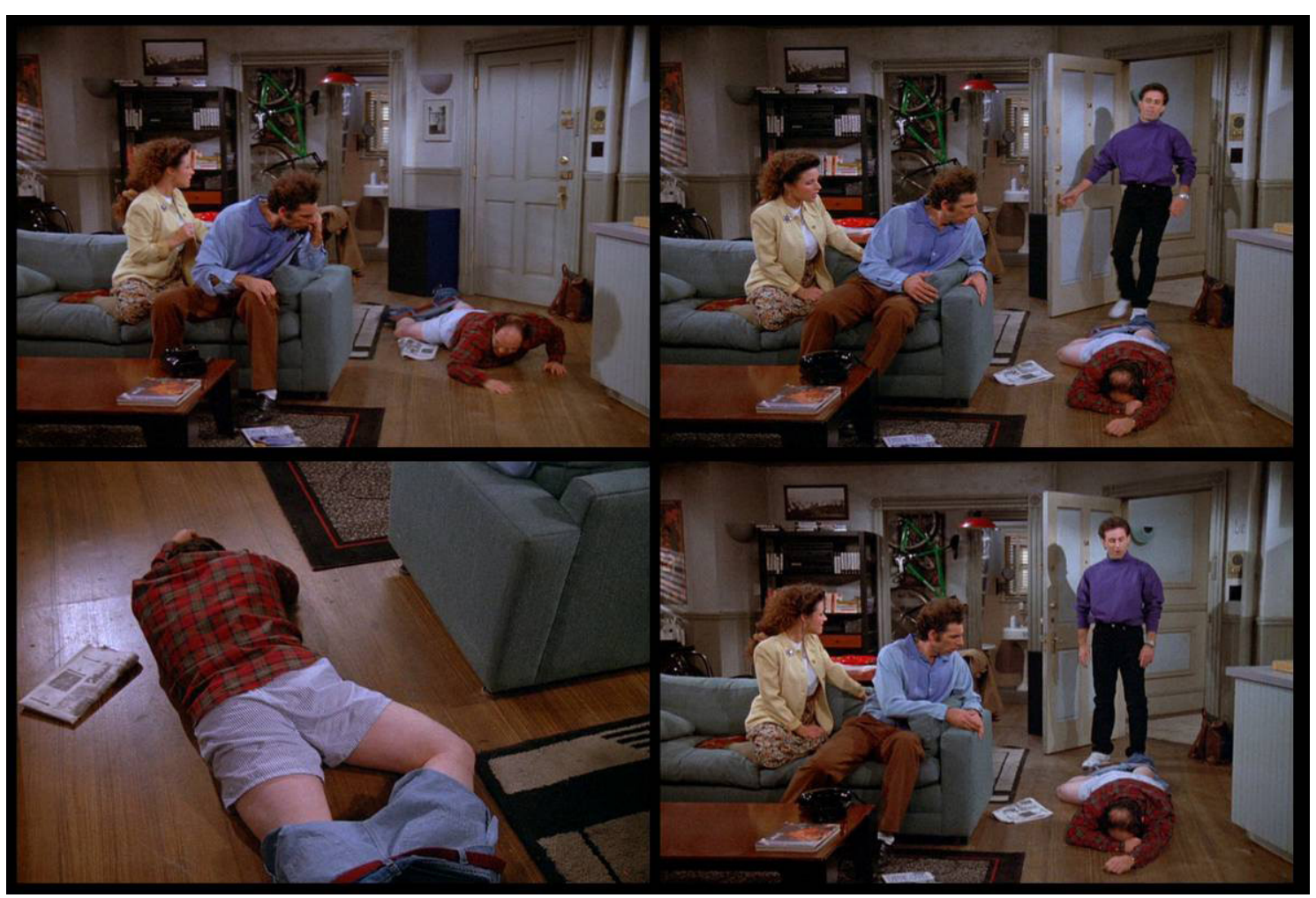

Fonte: DVD Seinfeld $3^{a}$ temporada, The Boyfriend (0317)

Também era comum que cenas gravadas em externa, antes da gravação do estúdio, tivessem sua performance repetida sem o cenário correto, mas em frente à plateia. Assim, uma caminhada pela rua gravada para compor a edição que ia ao ar virava uma caminhada dos personagens pelo cenário da casa de Jerry; um diálogo que acontecia dentro de um carro em movimento era repetido com as atrizes sentadas no sofá de um dos cenários fixos (Seinfeld $6^{\circ}$ temporada, disco 1/título 21/capítulo 2). 
- Figura 8 - Na esquerda, a imagem como foi inserida no episódio; na direita, 0 modo como foi apresentada à plateia

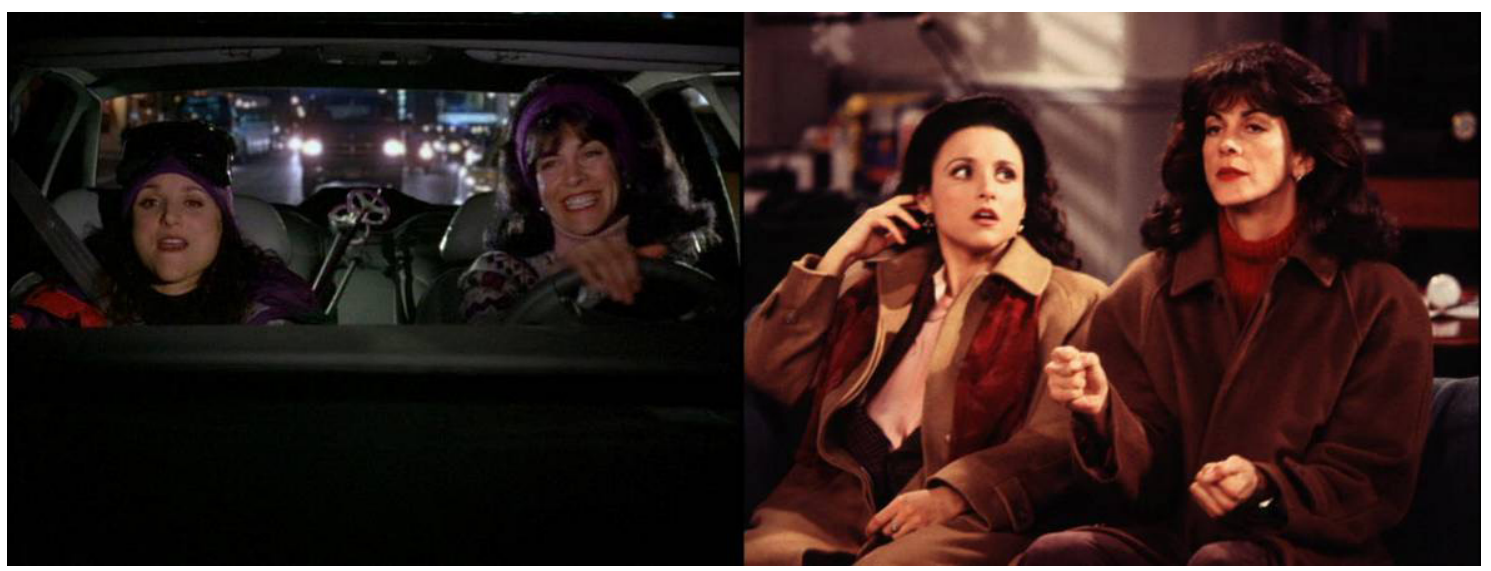

Fonte: Seinfeld $6^{\circ}$ temporada, disco 1/título 21/capítulo 2

Em outras situações, a própria plateia era levada para o local da externa. No episódio The Parking Space (0321) o desenhista de produção Tom Azzari (Seinfeld $3^{\circ}$ temporada, disco 4/capítulo 16) explica que uma arquibancada para cem pessoas foi montada ao ar livre, e que ele nunca soubera de algo assim feito em um sitcom.

Figura 9 - Um tour de force e técnico: gravação em multicâmera em externa, com presença de plateia

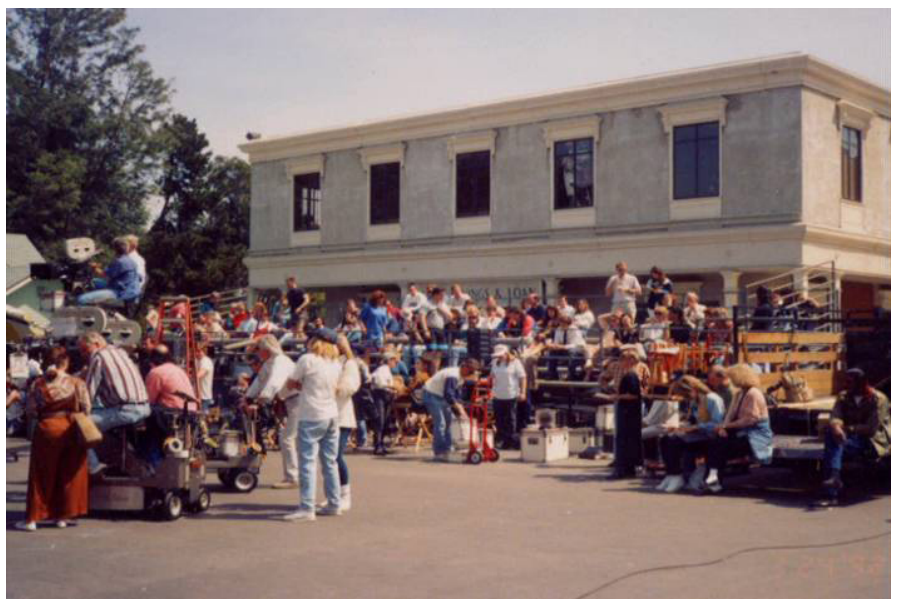

Fonte: Seinfeld $3^{\circ}$ temporada, disco 4/capítulo 16

Para o diretor Tom Cherones (Seinfeld $3^{\circ}$ temporada, disco 4/capítulo 16) o resultado não funcionou nada bem, porque os atores não podiam ouvir a reação dos espectadores e estes também não podiam acompanhar tão bem a 
encenação. No entanto, tais recursos de linguagem que sacrificavam a audiência das gravações nunca eram recusados em favor da plateia e se tornaram bastante frequentes na série.

Tanto quanto o programa ainda era dependente do modo de produção multicâmera, também era dependente de uma discreta montagem narrativa. No entanto, Seinfeld também levou para a produção de sitcoms certas técnicas de montagem antes reservadas à câmera única.

Mesmo a função narrativa da montagem começa a ser usada com uma sofisticação pouco comum no sitcom multicâmera. Em programas do gênero, podemos encontrar montagens paralelas. No entanto, quando isso acontece, a montagem tende a construir apenas a simultaneidade das cenas. Em Seinfeld, a montagem paralela gera sentidos. No episódio The Fix Up (0316), Jerry está em um restaurante com George, enquanto Elaine está em outro com sua amiga Cynthia. Enquanto comem e conversam, tanto George quanto Cynthia revelam suas expectativas de um relacionamento amoroso. As cenas são intercaladas com fragmentos curtos das conversas, opondo as expectativas de George e de Cynthia, e explicitando a possibilidade de um encontro entre os dois. A fragmentação das conversas pela montagem revela um paralelismo entre os personagens que dificilmente seria percebido se víssemosascenasintegralmente ou mesmo em longos trechos. Isso, mais uma vez, vai na contramão de uma encenação para ser vista "ao vivo" (na plateia, durante a gravação) e se coaduna com a lembrança de seu diretor, Tom Cherones (2011, 42'40"), de que Seinfeld era muito "feito na pós-produção".

No mesmo episódio, Jerry e Elaine (e depois Jerry e George e Elaine e Cynthia) conversam ao telefone para relatar sobre o encontro "arranjado". O que usualmente seria um diálogo com planos e contraplanos vira uma série de composições em split, mostrando simultaneamente ambos os personagens e suas reações nunca vistas pelo interlocutor.

- Figura 10 - Composições típicas da linguagem do vídeo, dependentes de pósprodução

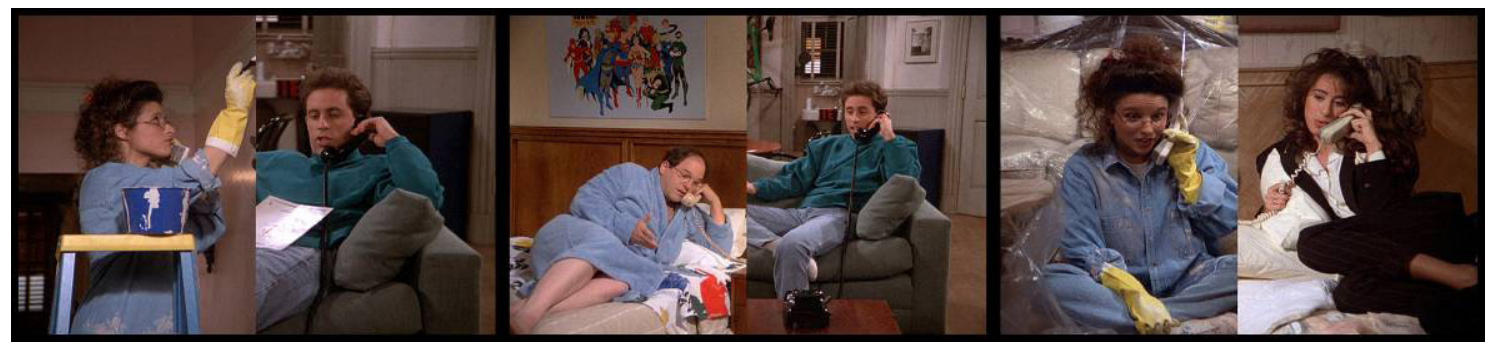

Fonte: DVD Seinfeld 3a temporada, The Fix Up (0316) 
A montagem também explora outras possibilidades de geração de sentido. Em The Bubble Boy (0407), a cena em que George é agarrado pelo Garoto da Bolha corta para a cena em que Jerry e Elaine, num restaurante de beira de estrada, são atacados pela garçonete (de quem Jerry decidiu retomar uma foto autografada). A última imagem do plano anterior e a primeira do plano seguinte se ligam pela composição e pela reiteração da briga.

\section{- Figura 11 - Rima produzida pela montagem}

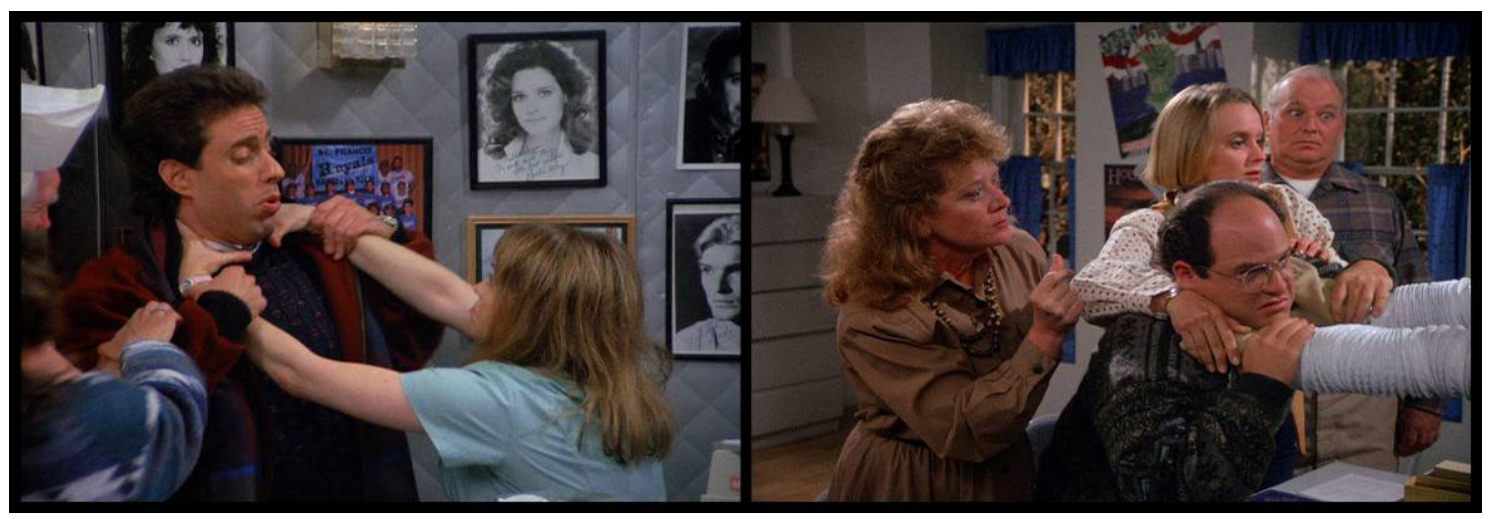

Fonte: DVD Seinfeld 4a temporada, The Bubble Boy (0407)

Ainda ao assistir aos episódios The Parking Garage (0306) e The Bizarro Jerry (0803), vemos como são atualizadas as experiências de Lev Kulechov, a "geografia criativa" e o "corpo cinemático", respectivamente. O prédio garagem, recriado em um pequeno estúdio, e Gillian, a namorada de Jerry com mãos ultra masculinas, remetem às bases de complexas técnicas de montagem soviéticas totalmente estranhas ao universo do sitcom multicâmera. Mesmo um mundano bulling do "cuecão" aplicado ao jovem George em The Library (0305) é mostrado em uma angustiante e cômica repetição do curto plano, da mesma forma que o próprio Einsenstein faz com o marinheiro que quebra o prato dos oficiais em $O$ Encouraçado Potenkim - obviamente com efeitos bem diferentes. 


\section{Figura 12 - Reiteração do gesto pela montagem}

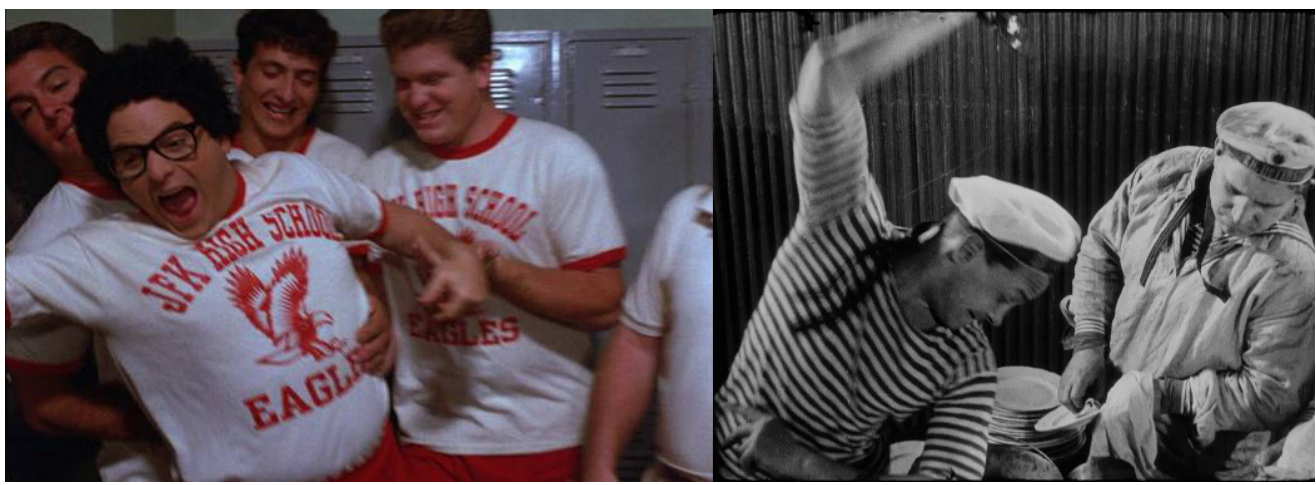

Fonte: DVD Seinfeld 3a temporada, The Library (0305); Continental (DVDs) DVD de O Encouraçado Potenkim.

A possibilidade de montar também permitiu toda sorte de flash backs, devaneios e fluxos de consciência, sumários narrativos e toda sorte de sintagmas narrativos. Isso permitiu o desenvolvimento de tramas que saíam das ações e diálogos circunscritos ao espaço de interação dos personagens, dando margem a mostrá-los em situações bastante diversas. Também possibilitou parodiar filmes, como em The Boyfriend (0317), em que Kramer e Newman relatam quando foram alvejados por uma cuspida, na saída de um jogo de beisebol. $O$ relato dos personagens ganha contornos de um filme a la Zapruder, com direito à textura com ruído e cores alteradas. O relato de Kramer e Newman remete ao filme de Oliver Stone, JFK, contemporâneo à produção do episódio.

Figura 13 - A paródia de JFK e do filme de Zapruder: ângulos e texturas impossíveis em um programa multicâmera

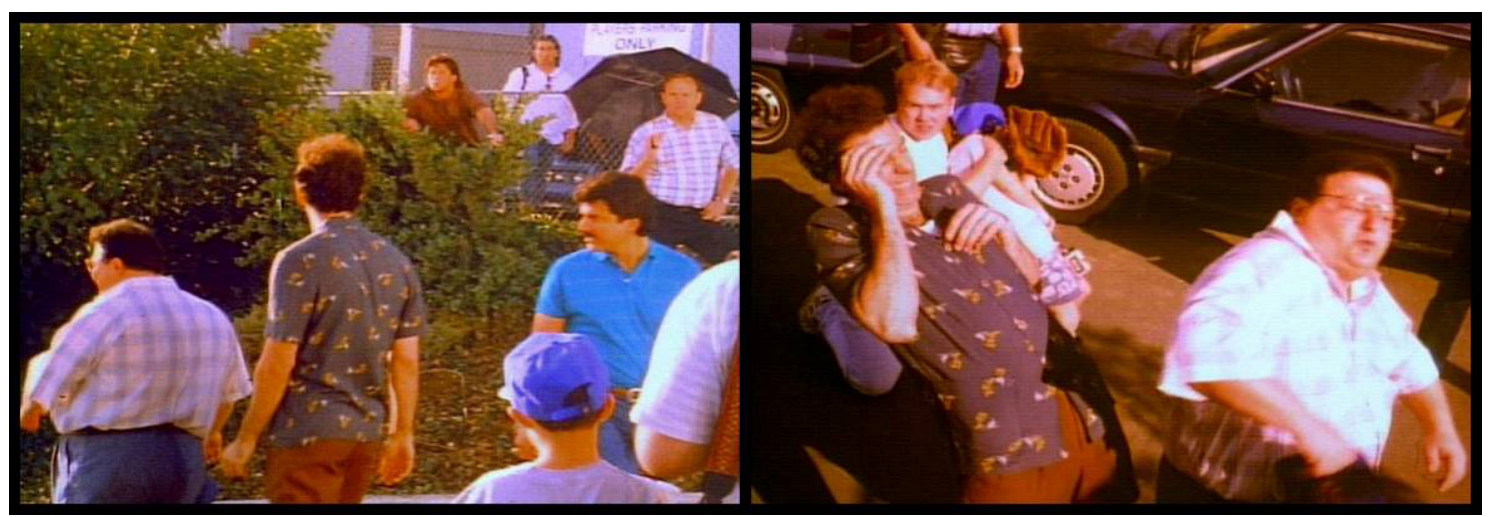

Fonte: DVD Seinfeld 3a temporada, The Boyfriend (0317)

\section{Considerações finais}

As opções narrativas e de estilo feitas em Seinfeld não são a única razão de seu sucesso. A crítica e a academia ainda vão se debruçar sobre a capacidade que 
o programa teve de dialogar com seu tempo, servindo como um microscópio sobre os tempos mortos e as miudezas que formam o interstício da vida contemporânea.

No entanto, seus aspectos formais de narrativa e de estilo não só serviram de suporte para o que o programa tinha a dizer, mas também ajudaram a colocar em perspectiva uma serie de convenções do gênero. Isso ampliou as possibilidades criativas para aqueles que vieram depois e deram novo fôlego a um gênero frequentemente apontado como moribundo (Levine, 2010, p. 10). É arriscado afirmar que sem Seinfeld não existiriam certos programas posteriores, mas é seguro afirmar que estes carregam uma clara influência do "show sobre o nada". As muitas linhas narrativas que se chocam no final de Arrested Development e Modern Family; as estruturas pouco usuais de The Office e/ou Curb Your Enthusiasm tornaram regulares ao que em Seinfeld era ousadia. A hibridização entre multicâmera e câmera única indicou procedimentos técnicos que ainda guardam algo do baixo custo e da rapidez, mas sugerem possibilidades de estilo que conferem aos programas uma "cara" muito própria (How I Met Your Mother).

Todas estas qualidades tornam Seinfeld singular. É sua mistura peculiar de temas e formas que o fazem tão engraçado e lhe garantem um lugar junto aos grandes sitcoms de todos os tempos, como I Love Lucy, The Dyck Van Dike Show, Taxi ou The Golden Girls. E ainda que alguns o tomem como uma sofisticada crônica do mundo contemporâneo, muitos outros o tomarão como excelente entretenimento, para rir por algumas boas horas. Não que haja nada errado com isso.

\section{Referências}

ACKERMAN, Andy: entrevista (parte 2) [Nov. 2007]. Entrevistadora: Jenny Matz. Los Angeles: The Television Academy Foundation, 2007. Disponível em: http:// www.emmytvlegends.org/interviews/people/andy-ackerman\# Acesso em: 14 nov. 2015.

BERCIANO, Rosa. La Comédia Enlatada: De Lucille Ball a Los Simpsons. Barcelona, Editorial Gedisa, 1999.

CHERONES. Tom: entrevista (parte 2) [Jun. 2011]. Entrevistadora: Amy Harrington. Los Angeles: The Television Academy Foundation, 2011. Disponível em: http:// www.emmytvlegends.org/interviews/people/tom-cherones\# Acesso em: 12 nov. 2015. 
KRUTNIK, Frank "A Spanner in the Works? Genre, Narrative and the Hollywood Comedian" In: KARNICK, Kristine B. e JENKINS, Henry. Classical Hollywood Comedy. New York, Routledge, 1995a.

LACEY, Nick. Narrative and Genre: Key concepts in media studies. New York, Palgrave, 2000.

LEVINE, Josh. Pretty, Pretty, Pretty Good: Larry David and the Making of Seinfeld and Curb Your Enthusiasm (Kindle Edition). Toronto, ECW Press, 2010.

MARC, David. Origins of the genre: in search of the radio sitcom. In: DALTON, Mary and LINDEN, Laura. The sitcom reader: america viewed and skewed. New York, State University of New York Press, 2005.

MILLS, Brett. The Sitcom. Edinburgh: Edinburgh University Press Inc., 2009.

MINTZ, Rick. The Great TV Sitcom Book. New York, Richard Marek Publishers, 1988.

MORREALE, Joanne. Critiquing the sitcom: A Reader. New York: Syracuse University Press, 2003.

PALLOTINI, Renata. Introdução à dramaturgia. São Paulo: Editora Ártica, 1988.

PELEGRINI, Christian H. Sujeito Engraçado: a produção de comicidade pela instância de enunciação em Arrested Development. 2014. 259 f. Tese (Doutorado em Meios e Processos Audiovisuais) Escola de Comunicação e Artes, USP, São Paulo, 2014.

ROUBINE, Jean Jacques. Introdução às Grandes Teorias do Teatro. Rio de Janeiro, Ed. Jorge Zahar, 2003.

SEINFELD SEASONS 1 - 9. Direção: Ackerman Andy. SONY PICTURES - SONY, 1989 2008.

SMITH, Greg M. Ploting a Show About Nothing: Patterns of Narration on Seinfeld. Creative Screenwriting, v. 2, n. 3, p. 82-90, 1995.

THOMPSON, Kristin. Storytelling in Film and Television. Cambridge, Harvard University Press, 2003.

Recebido em: 27/8/2016

Aceito em: 22/9/2016

Endereço do autor:

Christian Hugo Pelegrini <christian.pelegrini@gmail.com>

Instituto de Artes e Design - Campus Universitário

Universidade Federal de Juiz de Fora - Bairro Martelos

36036-330 - Juiz de Fora (MG) - Brasil 